\title{
Полското междувоенно двадесетилетие в огледалото на колективната рецепция
}

\begin{abstract}
Daradanova Elena, Polskoto mezhduvoenno dvadesetiletie w ogledaloto na kolektivnata recepcija (The Polish Interwar Period in the Mirror of Collective Reception). "Poznańskie Studia Slawistyczne" 18. Poznań 2020. Publishing House of the Poznań Society for the Advancement of the Arts and Sciences, Adam Mickiewicz University, pp. 275-281. ISSN 2084-3011.

The subject of this review is the reception of Polish interwar literature in Bulgaria, and particularly the anthology Polish Poetry between the Two World Wars (2019), by Panayot Karagyozov and the special issue of Literaturen vestnik (2018), devoted to Polish culture from that period.

The focus of the review is on the simultaneous reception of both translated poetry and literarycritical articles.
\end{abstract}

KEYwORDs: Polish interwar poetry; translation reception; anthological type of presentation

Полската художествена литература е добре позната в България. Рецепцията ѝ датира от края на 19 в. като сред първите преводачи е патриархът на българската литература Иван Вазов, който превежда от руски баладата „Алпухара“ от поемата на Адам Мицкевич „Конрад Валенрод“. Оттогава досега на български са преведени най-известните полски творци от ренесансовия колос Ян Кохановски до последната нобелова лауреатка Олга Токарчук и родения през 1979 г. поет Тадеуш Домбровски. Рецепцията на полската литература е синхронна и асинхронна, индивидуална и колективна. През последните десетилетия своевременно се превеждат на български и издават в самостоятелни книги редица съвременни автори, сред които са Ева Липска, Адам Загайевски, Анджей Сташук, Кшищоф Варга, Мариуш Шчигел, Еугениуш Ткачишин-Дицки и др. Колективната рецепция се осъществява чрез сборници с творби от няколко поети 
и от специализирани броеве на литературната периодика. Впечатляващ принос за колективната рецепция имат седмичникът Литературен вестник и полонистьт Панайот Карагьозов, които с подкрепата на Полския институт в София, са мощни популяризатори на съвременната полска култура.

През 2018 и 2019 г. Литературен вестник посвети тематични броеве за Збигнев Херберт, Густав-Херлинг Груджински, Олга Токарчук, полските нобелови лауреати, полската литература в огледалото на 1989 г. и полската литература между двете световни войни, а Панайот Карагьозов публикува антологиите Полска поезия в превод на Първан Стефанов (2014) ${ }^{1}$ и Полската поезия между двете световни войни (Карагьозов, 2019) и томче с осемдесет и три избрани стихотворения на Еугениуш Ткачишин-Дицки, озаглавено Това тяло можеше да бъде мое (2017).

Интересна пресечна точка на тематичната колективна рецепция са брой 34 за 2018 г. на Литературен вестник, посветен на полската междувоенна литература, и антологията Полската поезия между двете световни войни, които като своеобразен диптих представят краткия, но изключително интензивен период от полската литература, култура и изкуство. Съставителите на броя - Маргрета Григорова и Кристиян Янев - са подходили интердисциплинарно и върху 48 вестникарски страници са синтезирали преводни стихотворения, прозаични откъси, теоретични статии и подходящи илюстрации с живописни платна и скици от Виткаци, Титус Чижевски, Войчех Косак, Владислав Скочилас, Леополд Готлиб, Еугениуш Зак и Леон Хвистек. Чрез статията на Анджей Хвалба широката читателска публика се запознава с историята на възстановяването на изгубената полска държавност, а от биографичния очерк на Мачей Жуковски - със слабо познатата у нас фигура на архитекта на полската независимост и първи маршал на Сейма Юзеф Пилсудски.

${ }^{1}$ В издадените от П. Карагьозов през 2014 г. избрани преводи от Пьрван Стефанов поколението творци от междувоенния период заема важно място в концепцията на съставителя, отразяваща важната роля на П. Стефанов в процеса на рецепцията на полската литература на XX в., който „представя на езика на поезията многоликия и нееднозначен полски обществен и културен живот в периода между Първата световна война и края на тоталитаризма“" (Карагьозов, 2014, 6). 
Тематичният брой е доминиран от литературнокритически обзорни статии за периода и разработки за конкретни творци, написани от широк спектър съвременни полски литературоведи, сред които ca: Йежи Яжембски, Анджей Завада, Анна Марта Шчепан-Войнарска, Жанета Налевайк-Турецка, Агата Завишевска, Тадеуш Буйницки, Ярослав Фазан, Анна Нашиловска, Мария Олшевска, Богдан Баран, Йежи Квятковски, Ремигиуш Пьотровски, Томаш Стемпен, Иренеуш Опацки, Кшиштов Заяс, Фердинад Осендовски, Анна Венгжиняк. Наред със съставителите на броя със свои разработки участват българските полонистки Калина Бахнева и Радостина Петрова. Този съставителски избор очертава специфичен български модел на представяне на полската междувоенна литература, в чийто рецепционен процес литературнокритическият, съответно научният дискурс имат специфична опосредстваща роля.

Сред включената в броя художествена литература преобладават вече публикувани преводи на стихотворения от най-известните междувоенни поети, но също така са включени и неотпечатвани досега прозаични откъси от Снобизъм и прогрес на Стефан Жеромски, Генерал Барч на Юлиуш Каден-Бандровски, Кръстоносии на Зофия Косак и Третият пол на Тадеуш Доленга-Мостович, както и разказът Сивата стая от Стефан Грабински. За пръв път българският читател има възможност да се запознае и с Уводните думи на сп. Скамандър и Манифеста по въпроса за футуристичната поезия.

От своя страна Панайот Карагьозов в антологията фокусира читателското внимание върху поезията от периода и е подбрал както публикувани вече, така и преведени специално за антологията стихотворения и поеми от поетите: Леополд Стаф, Болеслав Лешмян, Йежи Либерт, Юлиан Тувим, Ярослав Ивашкевич, Кажимеж Вежински, Мария Павликовска-Ясножевска, Кажимера Илаковичувна, Владислав, Броневски, Бруно Яшенски, Станислав Млодоженец, Титус Чижевски, Александър Ват, Тадеуш Пайпер, Юлиан Пшибош, Юзеф Чехович, Константи Илдефонс Галчински, Чеслав Милош и Кшищоф Камил Бачински. Изборът на деветнадесетимата поети е направен въ3 основа на наличния преводен фонд и необходимостта да бъде представен възможно най-широко характерният за периода естетически и идеологически плурализъм. Новопреведените стихотворения от 
Яшенски, Млодоженец и Чижевски разширяват представата за поетиката на полския футуризъм, а тези от Пайпер и Пшибош акцентират върху авангардната програмна идея за града, масите, машините и общото между материалното и поетическото строителство. Включените стихотворения от К. Илаковичувна допълват рецепцията на поетичния кръг Скамандър и неговите „сателити“, а емблематичните творби на Чехович и Бачински изразяват катастрофизма, с който е белязан краят на междувоенния период.

Изключителен интерес за българския читател представляват програмите и манифестите на литературните направления от периода: Уводните думи на сп. Скамандър, Манифестът на футуристичната поезия на Яшенски, За делогизацията на поезията и От кониепиията за природата до самата природа на Чижевски и Отправна точка и Метафора на съвременността на Пайпер. Сполучливо издателско хрумване са факсимилетата на титулни страници на най-известните за периода списания, които тематично и визуално разграничават принадлежащите към даденото поетическо направление автори.

Пространният предговор към антологията наподобява миниистория на постиженията на полската литература. Панайот Карагьозов представя спецификата на междувоенната полска поезия през призмата на еволюцията на полската художествена словесност от времето на Средновековието до началото на 20 век. Той се спира върху установяването на нов тип държавност във Втората Жечпосполита и отбелязва, че на стремежите за централизация на културния живот от страна на режима на санацията се противопоставя невиждан до този момент идеен и естетически плурализъм, метафорично изразен със стиха на Юлиан Пшибош „Въздухът е задушен от знамена“ (вж. Карагьозов, 2019, 14).

В предговора периодът е представен както като синтез от новаторство и традиции, така и като стремеж на младите поети да се съизмерват не с постиженията на миналото, а с бъдещето. Карагьозов посочва, че „разделителните граници“ между „стари“ и „млади“ са опозициите природа - техника и минало - бъдеще. Обърнато е внимание върху промените в тематиката, езика, лексиката и поетиката на всички участващи в междувоенното двадесетилетие поети и че пресечната точка на многопосочното им творчество е градът. Авторът подчертава, че 
след като Позитивизмът въвежда градската тематика в прозата, междувоенният период урбанизира поезията (вж. Карагьозов, 2019, 36).

Карагьозов проследява генезиса на основните явления и отбелязва, че „феноменална за междувоенното двадесетилетие е симбиозата между литературната периодика, литературните кабарета, формалните и неформални литературни групи и прокламираните от тях програми и манифести“ (пак там, 24). Съставителят прави кратък преглед на връзката на полската преса с литературата от появата на първите полски списания и вестници (Merkuriusz Polski и Monitor) до междувоенното двадесетилетие, през което са излизали 20000 периодични издания. П. Карагьозов отбелязва, че преплитането на литературния живот с литературния процес води началото си от „литературните четвъртьци“ на последния полски крал Станислав Юзеф Понятовски и достига кулминацията си в артистичните варшавски кабарета като Qui Pro Quo и Pod Pikadorem, които масовизират и комерсиализират елитарната младополска традиция на краковските Jama Michalika и Zielony balonik.

Специално внимание е отделено на програмите и манифестите. П. Карагьозов припомня, че още през Ренесанса Миколай Рей и Ян Кохановски започват да „самоанализират“ полската художествена словесност и да очертават перспективите ѝ. Спорове по какъв път трябва да продължи полската литература водят Кажимер Броджински и Ян Шнядецки и др., но най-осезателно споровете и идеите за настоящето и бъдещето на полската литература очертават множеството междувоенни манифести и програми. Чрез отделните програми съставителят показва сходствата и разликите между футуристите, скамандритите и представителите на различните авангардни направления. Той се спира по-подробно върху текстовете на „програмотвореца“ Тадеуш Пайпер, който „разграничава календарното от културното летоброене“ (35), определяйки за начало на културното столетие годината на започналата Пьрва световна война. Карагьозов предполага, че ако към известната формула на Пайпер „3М“ (miasto-masa-maszyna) се добави и метафората от програмата Метафората на съвременността, максимата успешно може да се трансформира в „4М“. Съставителят подчертава, че „младополският символ отстъпва място на междувоенната метафора, която заедно 
с поантата, наред с иманентно-литературните функции реализира законите на езиковата икономия“ (21).

Карагьозов посочва, че междувоенният период е пик на жените литераторки. Въпреки че в антологията със стихове са представени само Мария Павликовска-Ясножевска и Кажимера Илаковичувна, съставителят прави преглед на присъствието на дамите в литературата от времето на дъщерята на княз Мешко Втори, Гертруда, която записва на латински сто свои молитви. Изредени са най-известните литераторки от различните епохи и се посочва, че поетесите и писателките от периода между двете световни войни към традиционните представи за жената като „Майка Полша“ добавят образа на полякинята творец. Приятна доза екзотика внася краткото описание на живота и творчеството на ромската поетеса Бронислава Вайс, по-известна като Папуша, чиято поезия е в духа на изконната циганска баладичност, но изпята от пьрво лице единствено число.

Към творците от междувоенния период съставителят причислява и т.нар. колумбовци - поетите, които са родени около 1920 г. и които в началото на Втората световна война полагат своите зрелостни изпити. Те развиват и изразяват в творбите си силно чувство за поколенческа принадлежност и обреченост. Повечето от тях загиват съвсем млади по време на войната и Варшавското въстание, но оставят впечатляващо зряло наследство. По аналогия с утвърденото определение за писателите, взели участие в Пьрвата световна касапница, като „изгубеното поколение“, Карагьозов нарича тези младежи „поетите от изтребеното поколение“ (47) и лаконично заключава, че началото на междувоенния период поставят творците от пьрвата генерация, а неговата Лебедова песен изпяват поетите-зрелостници, загинали по време на Втората световна война.

Студията на П. Карагьозов, която е интегрална част от антологийния сборник, и статиите от полски и български литературоведи в специалния брой на Литературен вестник потвърждават рецепционната стратегия междувоенният период да достига до българската публика не само чрез преводи на художествена литература, но и чрез литературоведски текстове. Научните текстове изпълняват компенсаторна функция - те опосредствано заместват непреведените на български език художествени феномени и липсата на идентични на тях 
в литературата на приемащата страна. Едновременно с това, вписвайки междувоенните явления в целокупната история на полската литература, студията на съставителя на антологията свързва процеса на читателска рецепция на художествените текстове с вече формираната българска представа за полската литература като цяло.

\section{Литература}

Григорова, М., Янев, К., (съст.) (2018). Полската литература между двете световни войни. „Литературен вестник“, бр. 34.

Карагьозов, П. (2014). Прости са пътищата навред, но и безпътицата е вредом... В: Полска поезия в превод на Първан Стефанов. Съст. П. Карагьозов. София: УИ „Св. Климент Охридски“, Полски институт София, с. 5-19.

Карагьозов, П., (съст.) (2019). Полската поезия между двете световни войни. Второ допълнено издание. София: УИ „Св. Климент Охридски“. Пьрво издание: София: УИ „Св. Климент Охридски“, 1996.

Карагьозов, П. (2019). Полската поезия между двете световни войни. Предговор. В: Полската поезия между двете световни войни. Съст. П. Карагьозов. Второ допълнено издание. София: УИ „Св. Климент Охридски““.

Grigorova, M., Ânev, K., (sast.) (2018). Polskata literatura meždu dvete svetovni vojni. „Literaturen vestnik“, br. 34.

Karag'ozov, P. (2014). Prosti sa patisata navred, no i bezpaticata e vredom... V: Polska poeziâ v prevod na Parvan Stefanov. Sast. P. Karag'ozov. Sofiâ: UI „Sv. Kliment Ohridski“", Polski institut Sofiâ, s. 5-19.

Karag'ozov, P., (sast.) (2019). Polskata poeziâ meždu dvete svetovni vojni. Vtoro dopalneno izdanie. Sofiâ: UI „Sv. Kliment Ohridski““. P’rvo izdanie: Sofiâ: UI „Sv. Kliment Ohridski“", 1996.

Karag'ozov, P. (2019). Polskata poeziâ meždu dvete svetovni vojni. Predgovor. V: Polskata poeziâ meždu dvete svetovni vojni. Sast. P. Karag'ozov. Vtoro dopalneno izdanie. Sofiâ: UI „Sv. Kliment Ohridski““.

http://www.bsph.org/members/files/pub_pdf_1614.pdf.

https://www.goodreads.com/book/show/49653037. 